\title{
АУДІОКОРЕКЦІЯ \\ ЦЕНТРАЛЬНИХ МЕХАНІЗМІВ РЕГУЛЯЦІї ФУНКЩЇ̈ ДИХАННЯ У ДІТЕЙ З БРОНХООБСТРУКТИВНИМ СИНДРОМОМ
}

Калашнікова Л. $\boldsymbol{\epsilon . , ~ д о ц . , ~ к . б . н . , ~ д о ц е н т ~ к а ф . ~ Б М І , ~}$ ORCID 0000-0001-5816-134X e-mail doc_hom2000@yahoo.com

Бойчик К. О., ORCID0000-0002-5320-9030 e-mailboychikksenia@gmail.com

Національний технічний університет України "Київський політехнічний інститут імені Ігоря Сікорського" Толкач C. I., с.н.с. відділення захворювань органів дихання,

ORCID0000-0002-9508-7932

e-mail svitlana.tolkach@gmail.com ДУ «Інститут педіатрії акушерства і гінекології НАМН України» Київ, Україна

Реферат - В статті запропоновано розробку методики для покращення бронхіальної прохідності у дітей з бронхообструктивним синдромом за допомогою впливу аудіо сигналу. Обрано три мелодії різного компонентного складу, а саме: шум океану, колискову та уривок з «Чарівної флейти» Мочарта. Надалі здійснено аналіз їх амплітудно-частотних характеристик (АЧХ) за допомогою середовища Matlab, щзо дало змогу побачити відмінності АЧХ підібраних аудіосигналів. Для изьгго використовували функцію перетворення Фур'є, яка є математичною основою спектрального аналізу сигналів. Було виявлено, шо для колискової характерна відсутність високочастотного компонента, а в двох інших мелодіях він наявний і проявлясться з невисокою амплітудою.

В роботі застосовувалися такі методи діагностики, як спірографія та електроенцефалографія, для реєстрації оцінки функиіонального стану пацієнтів. Обрано декілька показників спірографії, щзо є найінформативнішими при виявлені бронхообструктивного синдрому, основні з яких: ОФВ1 та індекс Тіффно. Встановлено їх покращення під впливом музики $i$, відповідно до цього, підвищення характеристик біоелектричної активності мозку. Аналізуючи зміну абсолютноі спектр-потужності ЕЕГ-ритмів, прослідкували реактивність мозку. Отримали, що зазначений показник найбільше підвищився в альфа-ритму. Для об'єктивізації оцінки електроенцефалограми було введено інтегральний індекс активності мозку, завдяки якому можливо простежити вклад головних хвильових ритмів відносно повільнохвильової складової ЕЕГ. Виявлено, щзо обраний коефіцієнт покрашився у більшої частини обстежених.

Запропонована методика зможе використовуватися з метою зменшення медикаментозного впливу та підвищення ефективності профілактичних й лікувальних процесів.

Бібл. 14, рис. 6, табл. 1.

Ключові слова - бронхообструктивний синдром, музикотерапія, “ефект Моцарта”, спірографія, електроениефалографія, перетворення Фур'є.

\section{I. Ветуп}

За даними літератури, хвороби, які вражають органи дихання, широко розповсюджені в світі. Як правило, такі захворювання супроводжуються порушенням прохідності бронхіального дерева функціонального або органічного походження $[1,2]$. Такий стан називають бронхообструктивним синдром (БОС). В патогенезі даного синдрому велика роль відводиться нейрорефлекторним механізмам, які формують первинні порушення, що з'являються не в органі-мішені, а в апараті нервового контролю та реалізуються через механізми вегетативної і нейрогуморальної регуляції [1, 3]. Важлива роль в комплексному лікуванні хворих з БОС відводиться методам психологічної корекції, серед яких все більший і закономірний інтерес викликає музична терапія.

Робота присвячена розробці методики впливу аудіосигналу на активацію резервних і адаптивних можливостей організму, для зменшення ризику розвитку обструктивного синдрому бронхо-легеневої системи.

Мета роботи: вивчення центральних механізмів регуляції тонусу гладкої мускулатури бронхів у дітей зі схильністю до бронхоспазму. 


\section{II. Музикотерапія та "ефект моцарта"}

Музикотерапія - це цілеспрямоване застосування музики чи музичних елементів для досягнення терапевтичних цілей, а саме, відновлення, підтримки та сприяння психічному й фізичному здоров'ю [4].

Як свідчать клінічні спостереження, найбільш сприятливий вплив на людину здійснює класична музика: вона заспокоює, знімає м'язову напругу, тонізує, сприяє зниженню тривожності. Особливу увагу вчені приділяють унікальному впливу музики Моцарта на мозок людини та її фізичний стан. Даний ефект називають “ефектом Моцарта".

Музика Моцарта найбільшою мірою містить високочастотні звуки, які надають лікувальну дію і стимулюють мозок: для неї характерне перетікання звуків "голосно-тихо" в тридцятисекундному діапазоні, що відповідає характеру біотоків і біоритмам головного мозку. Резонанс в корі головного мозку викликає регулярні 20-30-секундні секвенції повільних творів Моцарта, наближені до тимчасового періоду ЕЕГ-мозкових хвиль і повторювані у Моцарта частіше, ніж в іншій музиці [5].

\section{III. Методика дослідження}

Обстежено 8 дітей у віці від 10 до 12 років зі схильністю до бронхоспазму. Діти перебували на лікуванні у відділенні для дітей старшого віку $з$ патологією органів дихання «ІІнституту педіатрії акушерства і гінекології НАМН України».

Всі обстежені - правші без спеціальної музичної освіти. Дослідження проводилося на добровільних засадах 3 дотриманням всіх принципів біомедичної етики.

Для природної стимуляції головного мозку 3 метою регулювання фізіологічних функцій i активації фізичного ресурсу людини використовувалися музичні уривки, які були обрані на основі аналізу літератури 3 функціональної музики.Таким чином, було підібрано наступні мелодії: шум океану - аудіосигнал 1 , колискова - аудіосигнал 2, «Чарівна флейта» Моцарта аудіосигнал 3. Запропоновано звукові стимули різного компонентно-структурного складу, що відрізняються наявністю мелодійного компонента i швидкістю відтворення.Така форма впливу спрямована на регуляцію вегетативних процесів, моделювання позитивного психоемоційного стану, релаксацію.
Згідно завданням нашого дослідження були вивчені як показники функції зовнішнього дихання за даними спірографії, так і спектральні характеристики біоелектричної активності мозку за допомогою електроенцефалографії (ЕЕГ) у відповідь на аудіо-сигнал.

\section{A. Cnірографія}

Спірографія - метод графічної реєстрації змін легеневих об'ємів при виконанні природних дихальних рухів і форсованих дихальних маневрів [6].

Метод застосовується для оцінювання функціонального стану системи зовнішнього дихання. У обстежені використовували комп'ютерний діагностичний комплекс "СпіроСпектр+". При виконанні проб дотримувались основних вимог до спірографічніх обстежень [6]. Реєстрацію та аналіз показників здійснювали за допомогою програмного забезпечення "Спіро-Спектр". Для оцінювання функціонального стану системи зовнішнього дихання були обрані окремі показники [7]:

- Форсована життєва ємність легень - об'єм повітря, що видихається при максимально швидкому і сильному видиху (ФЖЕЛ, л).

- Об'єм повітря, що видихається протягом першої секунди форсованого видиху (ОФВ1, л).

- Миттєва об'ємна швидкість після видиху $25 \%, 50 \%, 75 \%$ ФЖЕЛ, що відраховуються від початку видиху (МОШ25, МОШ50, МОШ75 відповідно, л/с).

- Індекс Тіффно (ОФВ1/ФЖЄЛ, \%).

\section{В. Електроенцефалографія}

Електроенцефалографія (ЕЕГ) - це метод функціональної діагностики, який дозволяє оцінити стан головного мозку людини на основі його біоелектричної активності.

Проводилося ЕЕГ - дослідження за допомогою системи комп'ютерної електроенцефалогpaфi DX-5000 practic, електроди розташовувалися згідно міжнародної системи 10-20[8].

ЕЕГ-ритми реєструвалися за наступним протоколом: 1) Реєстрація фонової ЕЕГ протягом 60 сек; 2) Реєстрація ЕЕГ з прослуховуванням музики в навушниках протягом 180 сек; 3) Реєстрація фонової ЕЕГ протягом 60 сек.

Опрацювання отриманих записів ЕЕГ здійснювалося для основних ритмів (табл. 1) за допомогою програми Brain Test. 
Таблиця 1. Основні ритми ЕЕГ[9]

\begin{tabular}{|c|c|c|}
\hline Ритм & $\begin{array}{c}\text { Yacmoma, } \\
\Gamma u\end{array}$ & $\underset{\text { мкВ }}{\underset{\text { Амплімуда, }}{2}}$ \\
\hline Альфа & $8-13$ & $5-100$ \\
\hline Бета & $14-40$ & до 20 \\
\hline Дельта & $0,5-4$ & $20-200$ \\
\hline Тета & $4-8$ & $20-100$ \\
\hline
\end{tabular}

\section{IV. Аналіз аудіосигналів}

Аналіз аудіосигналів відбувався на основі дослідження їх частотного спектру. Для аналізу акустичних сигналів використовували їх фізичні параметри, отримати які можна за допомогою спектрального аналізу. Математичною основою спектральнго аналізу сигналів є перетворення Фур'є. Перетворення Фур'є дозволяє уявити безперервну функцію $\mathrm{f}(\mathrm{x})$ (сигнал), визначену на відрізку $\{0, \mathrm{~T}\}$ у вигляді суми нескінченого числа (нескінченого ряду) тригонометричних функцій (синусоїд і /або косинусоїд) з певними амплітудами і фазами, що також розглядаються на відрізку $\{0, T\}[10,11]$. Такий ряд називається рядом Фур'є.

Перетворення Фур'є може бути записано у вигляді:

$$
f(x)=\frac{a_{0}}{2}+\sum_{k=1}^{+\infty} A_{k} \cos \left(2 \pi \frac{k}{\tau}+\theta_{k}\right),
$$

де $k$ - номер тригонометричної функції (номер гармоніки);

$\tau$ - відрізок, де функція визначена (тривалість сигналу);

$A_{k}$ - амплітуда k-ої гармонійної складової;

$\theta_{k}$ - початкова фаза k-ої гармонійної складової;

Спектральний аналіз для обраних мелодій здійснювався за допомогою перетворення Фур'є у середовищі Matlab [12]. Отримані результати наведені на рис. 1.

На представлених графіках помітно, що серед обраних мелодій, у колискової відсутній високочастотний компонент, а "Чарівна флейта" Моцарта та шум океану поєднали у собі майже всі частоти чутного діапазону. Найбільша амплітуда в них проявляється при низьких та середніх частотах, а при високих, навпаки, амплітуда зменшується.

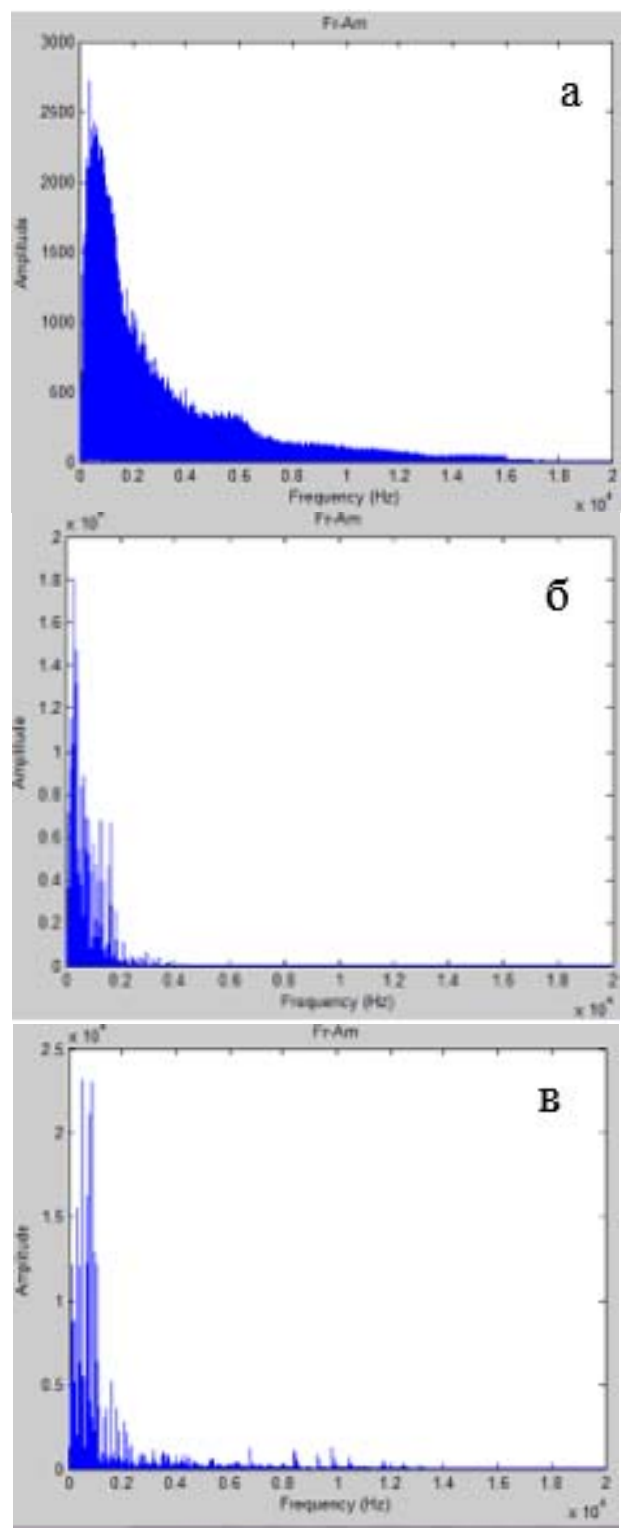

Puc. 1. Графік залежності амплітуди від частоти для: а)шуму океану, б) колискової, в) "Чарівної флейти"

\section{V. Аналіз одержаних результатів}

\section{А. Аналіз спірограми}

Аналіз результатів спірографічних досліджень свідчить, що всі зазаначені характеристики функції дихання мають тенденцію до нормалізації після прослуховування музичних композицій. В ході дослідження було виявлено, що зміни функції дихання мають різну ступінь в залежності від впливу аудіосигналу.

При аналізі результатів спірографії оцінювалися зміни найголовніших показників при бронхіальній обструкції [13]:

- ОФВ1 - показник, зниження якого вказує на порушення бронхіальної прохідності (товщини просвіту і еластичності бронхів). 
- Індекс Тіффно - показник, зменшення якого свідчить про збільшення бронхіального опору на видосі.

Порівняльний аналіз результатів досліджень впливу аудіосигналу різного компонентного складу демонструє, що найбільші зміни показників функції дихання спостерігаються після прослуховування "Чарівної флейти”. Таким чином при впливі аудіосигналу 3 , ОФВ1 збільшився у $100 \%$ обстежуваних в середньому на $20,0 \pm 0,1 \%$. А індекс Тіффно покращився у $62,5 \pm 0,2 \%$ паціентів в середньому на $6,0 \pm 0,1 \%$ (рис. 2).

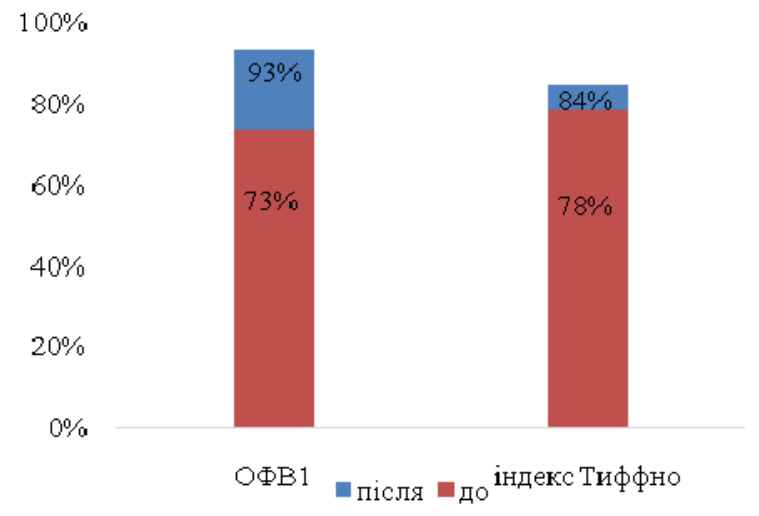

Рuc. 2. Зміна спірографічних показників

У37,5 1,0 \% обстежуваних після прослуховування "Чарівної флейти" покращилися абсолютно усі спірографічні показники, що $є$ важливими при виявленні та лікуванні бронхообструктивного синдрому.

У результаті проведених досліджень виявлено характерні адаптивні зміни системи зовнішнього дихання обстежених.

\section{В. Аналіз електроенцефалограми}

За результатами аналізу фонової ЕЕГ (ЕЕГ до прослуховування музики) досліджені не мають патологічних відхилень у електричній активності мозку.

Вплив аудіосигналів (умови після прослуховування музики) надав значні відмінності в характеристиках біоелектричної активності головного мозку.

Реактивність мозку оцінювалася по зміні абсолютної спектр-потужності (АСП). Виявлено, що після прослуховування «Чарівної флейти» найкраще змінюється АСП альфаритму. Підвищення зазначеного показника спостерігається у $37,5 \pm 0,5$ \% обстежених, тета-

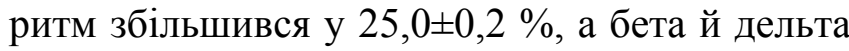
- у $12,5 \pm 0,3 \%$ (рис. 3). Зміна АСП основних ритмів відносно АСП фонової ЕЕГ складає для: альфа-ритму - 28,8 $\pm 0,2 \%$; тета $-28,1 \pm 0,3 \%$, дельта - 17,3 $\pm 0,4 \%$; бета $-15,3 \pm 0,3 \%$ (рис. 4).

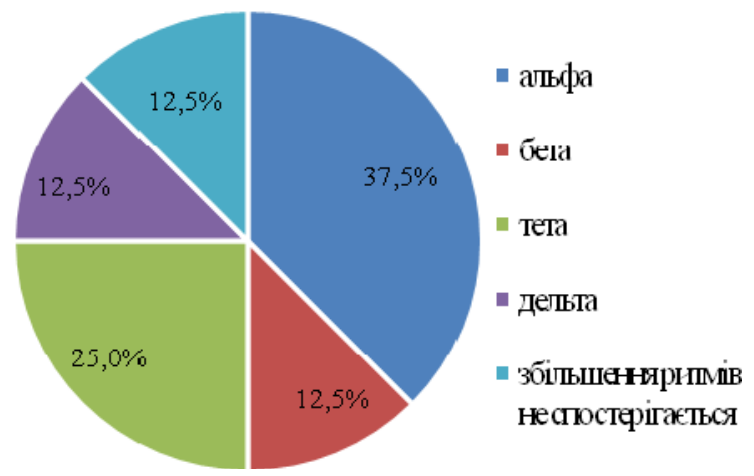

Рис. 3. Відсоткові зміни ритмів у групі обстежених

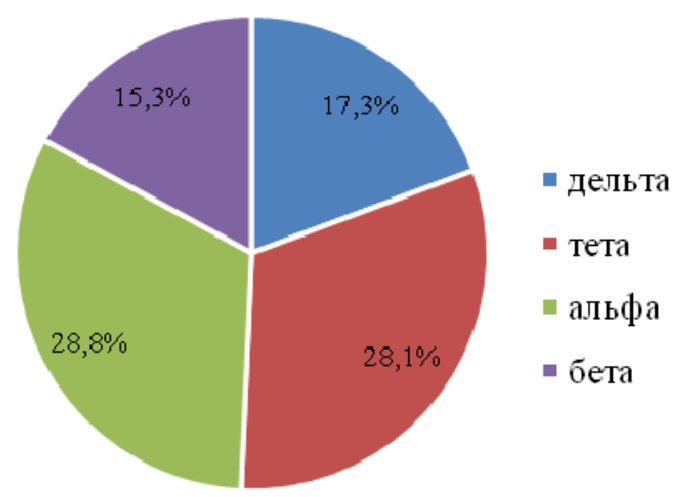

Рис. 4. Зміна ритмів ЕЕГ після прослуховування

Як випливає з аналізу даних, домінуючим ритмом $\epsilon$ альфа-ритм мозку з субдомінуванням тета-ритму.

Для об'єктивізації оцінки електроенцефалограми було застосовано метод інтегрального кількісного аналізу ЕЕГ-патерну. Він полягає в обчисленні інтегральних коефіцієнтів, що дозволяють визначити значимість окремих частотних спектрів ЕЕГ у формуванні цілісного патерну $[13,14]$.

У роботі ми розрахували інтегральний коефіцієнт активності мозкової діяльності, який показує вклад головних хвильових ритмів відповідно до повільної складової ЕЕГ. Обраний індекс являє собою співвідношення (альфа+ +бета)/(дельта+тета). Альфа та бета ритми - це основні ритми ЕЕГ. Синхронізація альфа та бета активності у неокортексі людини свідчить, що нервова система включає механізм самовідновлення та саморегуляції. Мозок покращує свою роботу, людина набуває психічну стійкість [8]. Повільнохвильовий компонент ЕЕГ - тета- та дельта-хвилі - це електрична активність мозку, яка характеризує стан пов- 
ної розслабленості. Підвищення потужності тета-активності свідчить про стан глибокого спокою, як перехід від спокійного неспання до сну. Такий стан ще розглядають як «ритм напруги»[9]. Є підстави пов'язувати зростання тета-ритму з процесами зниження гальмування (або зростання збудження). Надлишок посилених дельта-хвиль практично гарантує наявність порушень уваги і інших когнітивних функцій. Це пов'язане 3 тим, що дельта активність характеризує несвідомий стан або стан глибокого сну $[8,9]$.

Тому визначення долі ритмів ЄЄГ буде показником про стан електричної активності мозку при впливі музичних стимулів.

На рис. 5 представлені дані зміни індексу хвильвої активності мозку у восьми обстежених. Всі отримані дані оброблялися з використанням методів математичної статистики. Аналіз одержаних результатів дозволив сформувати 2 групи пацієнтів. Діти, у яких інтегральний індекс зменшився, складають першу групу. До неї відносяться $37,5 \pm 0,5$ \% обстежених (рис. 6), показник індексу котрих знизився в середньому на $16,7 \pm 0,2 \%$.Такі зміни свідчать про дезінтеграційні процеси хвильових функцій мозку. До другої групи увійшли пацієнти 3 підвищенням даного індексу. Збільшення коефіцієнту в середньому на $27,0 \pm 0,1 \%$ відбулося у $62,5 \pm 0,2 \%$ обстежених. Знаходження мозку у стані 3 переважанням ритмів характерним для стану фізіологічної норми свідчить про стабілізацію активності центральної нервової системи i, як наслідок, відновлення функцій організму, які насамперед залежать від центральних механізмів регуляції.

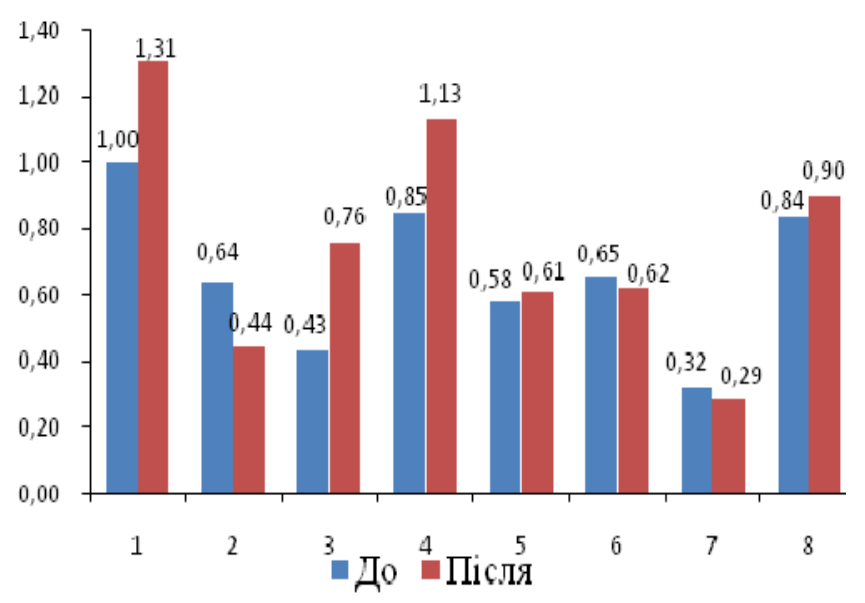

Pис. 5. Зміна інтегрального індексу активності мозку

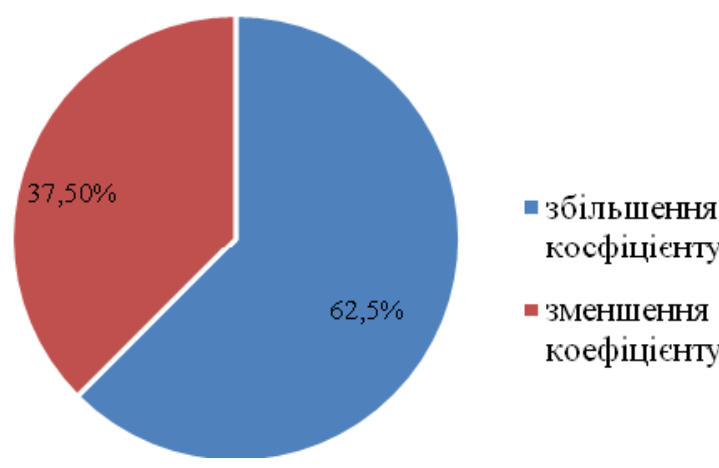

Рис. 6. Відсоткові зміни індексу у групі обстежених

\section{VI. Висновок}

В статті запропоновано методичні підходи для покращення бронхіальної прохідності у дітей з бронхообструктивним синдромом. Дана методика грунтується на застосуванні аудіосигналів 3 лікувальною метою.

Аналіз результатів проведеного дослідження показав:

1. Підвищення рівня головних показників легеневої вентиляції - ОФВ1 та індексу Тіффно, які збільшилися на $20 \pm 0,1 \%$ та $6 \pm 0,1 \%$ відповідно, що вказує на нормалізацію вентиляційної функції бронхів.

2. Найбільше підвищення (в середньому на $28,8 \pm 0,2 \%$ ) показників сумарної абсолютної спектр-потужності альфа-ритму у $37,5 \pm 0,5 \%$ всіх обстежених.

3. Збільшення інтегрального коефіцієнту активності мозкової діяльності у другій групі

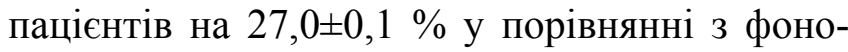
вими показниками.

4. Прослуховування аудіосигналу 3 призвело до підвищення інтегрального показника електричної активності неокортексу, що в свою чергу свідчить про зменшення повільнохвильової компоненти ЕЕГ. Такі зміни індексу супроводжувалися покращенням параметрів функції зовнішнього дихання та нормалізацією бронхіальної прохідності.

\section{ПЕРЕЛІК ПОСИЛАНЬ}

[1] Ісаев Д. Н. Психосоматичні розлади у дітей / Д. М. Ісаєв. СПб: Изд-во: «Пітер», 2016. - 512 с.

[2] Крижанівський Г.Н. Патологічні інтеграції в нервовій системі / Г.Н. Крижанівський // Бюл. експери. біології і медицини. - 2014. - Т. 129, №2. -С. 124-128.

[3] Юлишь Е. И., Сорока. Ю. А., Чернышева О. Е. О факторах риска развития бронхообструктивного синдрома у детей раннего возраста // Журнал "Здоровье ребёнка». 2015. - Т. 6, № 41. - 58c.

[4] Александр Федорович Белко. Музыка для восстановления. Сборник по музыкотерапии. Книга первая/ А. Ф. Белко. - 2017. -340c.- ISBN 978-5-4483-8766-1. 
[5] Дворецкий Л. И. Музыка и медицина. Размышления врача о музыке и музыкантах. М.: МЕДпресс-информ, 2014.

[6] Функціональні методи дослідження органів дихання у дітей. Пневмотахометрія: навчально-методичний посібник / Охотнікова О.М., Ткачова Т.М., Руденко С.М. - К., ВБ «Аванпост-Прим», 2014. - 95с.

[7] Довідник 3 дитячої пульмонології / Науково-методичне видання // Антипкін Ю.Г., Лапшин В.Ф., Уманець Т. Р. К.:ТОВ «Доктор-Медіа», 2011. - 254c.

[8] Конарева И. Н. Изменения электроэнцефалограммы и эмоционального состояния под влиянием прослушивания музыки / Конарева И. Н. // Ученые записки Таврического национального университета им. В. И. Вернадского Серия «Биология, химия». - 2017. - С. 40-47.

[9] Овчинникова Т. С., Изучение влияния музыкальных ритмов на человека / Овчинникова Т. С., Кузнецова Т. Г., Горбачева М. В. // Музыкальная психология и психотерапия № 4, 2014. - С. 41-45.

[10] Мясникова Н. В. Быстрое преобразование Фурье на осно- ве время импульсной модуляции сигнала//Датчики и системы. - 2000. -№2. - С.47-53

[11] Павлейно М. А., Ромаданов В. М. Спектральные преобразования в MATLAB Учебно-методическое пособие// СПб. $-2017 .-160 \mathrm{c}$.

[12] Болезни органов дыхания: Руководство по внутренним болезням. / Под ред. Н.Р. Палеева. - М.: Медицина, 2000. - C. 47-59, 74-75.

[13] Изнак А. Ф., Изнак Е. В. Количественные и топографические ЭЭГ-корреляты дисфункции некоторых мозговых систем при психических расстройствах // Материалы Всероссийской научно-практической конференции «Количественная ЭЭГ и нейротерапия».СПб.: Человек и здоровье, 2007. - С. 41.

[14] Острова Т. В., Черній В. І., Шевченко А. І. Алгоритм діагностики реактивності ЦНС методами штучного інтелекту. - Донецьк: Международный неврологический журнал. - 2007. - № 2. - С. 2-11. 